\title{
HYDROPOWER DEVELOPMENT AND ITS SUSTAINABILITY WITH RESPECT TO SEDIMENTATION IN NEPAL
}

\author{
Er. Durga Prasad Sangroula, PhD \\ Associate Professor, Pulchowk Campus, Institute of Engineering, Tribhuvan University
}

\begin{abstract}
Sustainable hydropower development is the basic for the economic development of Nepal. The current generating capacity of hydropower projects in Nepal is about $600 \mathrm{MW}$. Despite adequate availability of surface water, several water resources projects have not been yielding expected output primarily due to sedimentation problems, which were underestimated at design stage in most of the cases. Sediment production in Nepalese watersheds has generally been acknowledged to be the highest in the world and little reliable data of actual sediment production is available.

Attempts were made to study the sedimentation processes in the Kulekhani Reservoir, Nepal and efforts were made to find appropriate sediment management options to keep Kulekhani Reservoir Sustainable. This paper provides historical development of hydropower, opportunities and challenges in this sector. Problem associated with sediments in developing hydropower has been addressed.
\end{abstract}

Key words: Hydropower, sedimentation, sediment monitoring, sediment study and research.

\section{INTRODUCTION}

Nepal is one of the Himalayan countries with a high hydropower potential. The water resources of Nepal are regarded as one of the principal opportunities for future economic development of the country. As mentioned in the country report in the first International Summit on "Sustainable use of water for energy", some 225 billion $\mathrm{m} 3$ of surface water flows thorough Nepalese territory annually (WWC and IHA, 2003). This gives a specific runoff of about 0.12 million $\mathrm{m} 3 / \mathrm{km} 2 /$ year, being about four times the world average.

Nepal has more than 6,000 rivers and rivulets with a total length of about $45,000 \mathrm{~km}$. All the rivers from Nepal drain to the Ganges River in India through several river systems (see Figure 1.1). The major rivers of Nepal are shown in Figure 1.1. Koshi, Gandaki, and the Karnali are the major river systems in Nepal. These three rivers drain about $78 \%$ of mountains part and about $70 \%$ of the Nepalese territory (Bhusal, 2005).

Depending on the origin, Nepalese rivers are broadly classified as first grade, second grade and third grade. The rivers within origin from glacier on ice caped mountains above the snow line are first Grade Rivers, characterized by a perennial flow regime. Koshi, Gandaki and Karnali fall into this category. 


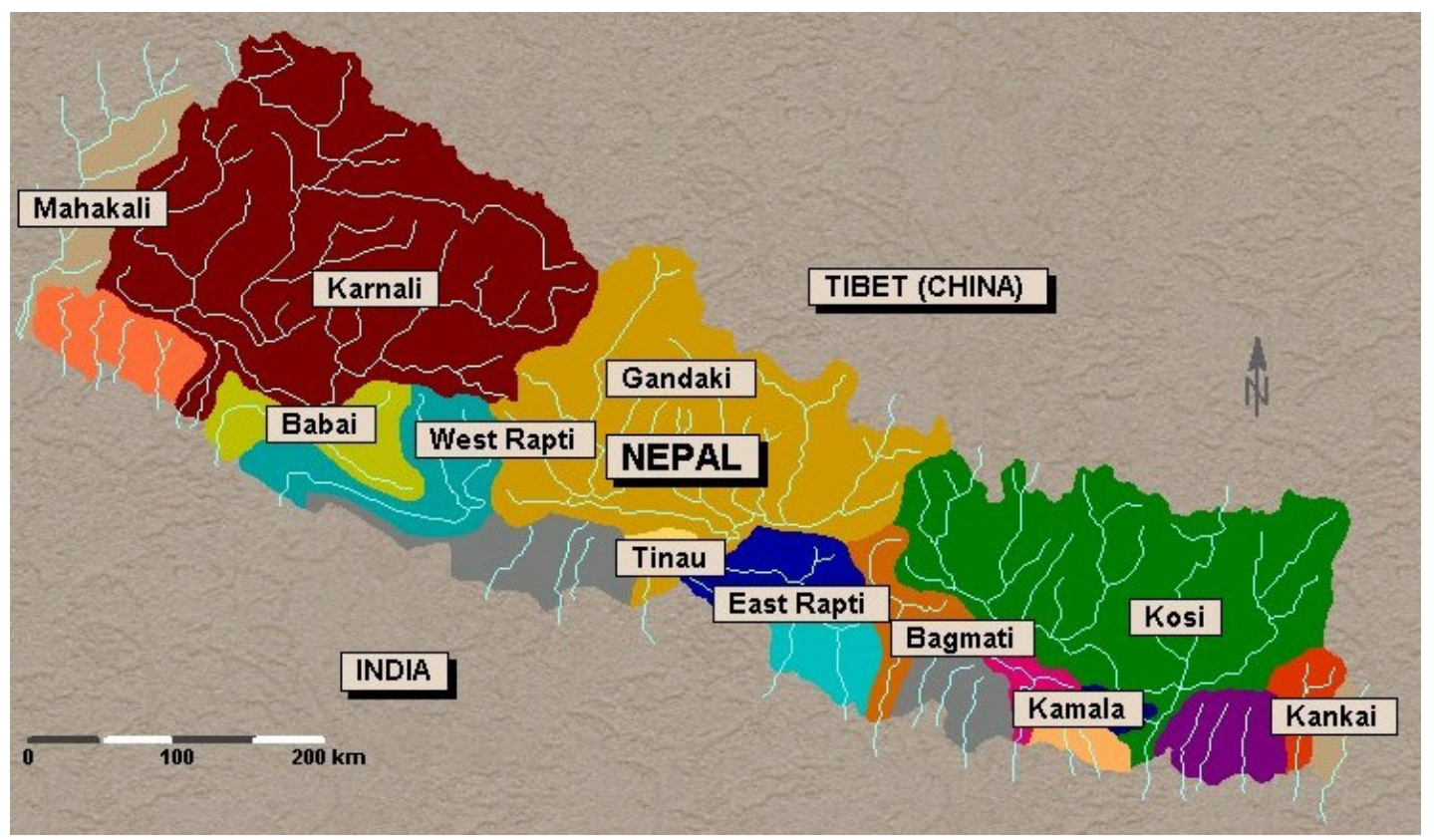

Figure 1.1: Major river systems with their corresponding catchment area (adopted form Galay et al., 2003)

The rivers with origin from the Mahabharat range are classified as second Grade Rivers. Mahabharat range falls below the snow line at about 5,000 masl (Bhusal, 2005), and while these rivers are also perennial, the variation of discharge between the dry and wet season is significantly different. The Mahakali, Babai, West Rapti, Tinau, East Rapti, Bagmati, Kamala, and Mechi are major rivers in this category (see Figure 2.1). The rivers with origin from the Siwaliks hills and below that region are classified as third Grade River. The Banganga, Manusmara, Hardinath are some of the rivers in this category. During dry season almost no flow is available for these rivers, however during monsoon season these rivers and streams are vulnerable to disasters.

Of the total capacity, the storage type of projects constitutes about $49 \%$ and the remaining $51 \%$ are run-of-river (RoR) projects. The current generating capacity of hydropower projects in Nepal is about 600 MW. Only about $20 \%$ of the population has access to electricity, of which only $5 \%$ of the rural population (WWC and IHA, 2003). However, Pandey (2003) reported that $40 \%$ of Nepali households have access to electricity

Most of the developed hydropower projects in Nepal are RoR type. Because of the seasonal variation of the river flow, there is excess power supply during the monsoon season (July-September) and shortage in the dry season. The only storage project Kulekhani is not able to fulfil power demand of the country during dry season. As a result, the country is facing load shading every year in all season.

Sedimentation is one of the major challenges for hydropower development in Nepal. This is because the sediment load in the Nepalese rivers is among the highest in the World. In contrast with some of the larger sediment producing watersheds in the world, the Karnali watershed of Nepal (see Table 1.1) produces more sediment per square kilometer than most others rivers (Galay et al., 2003). The main reason for the high sediment yield is that the mountains have been uplifted 
rapidly and the rocks have fractured and weathered more than most geologic zones in other mountains together with concentration of high precipitation.

Table 1.1: Comparison of specific sediment loads (Galay et al., 2003)

\begin{tabular}{|c|c|c|c|c|c|}
\hline Name of the River & $\begin{array}{l}\text { Fraser river in } \\
\text { B.C.,Canada }\end{array}$ & Karnali River, Nepal & $\begin{array}{l}\text { Mekong River, } \\
\text { Vietnam }\end{array}$ & $\begin{array}{l}\text { Yellow River, } \\
\text { China }\end{array}$ & $\begin{array}{l}\text { Indus River, } \\
\text { Pakistan }\end{array}$ \\
\hline Area, $\mathrm{km}^{2}$ & 250,000 & 43,560 & 800,000 & 770,000 & 960,000 \\
\hline Mean annual flow, $\mathrm{m}^{3} / \mathrm{s}$ & 3,410(Mission) & 1,389 (Chisapani) & 15,000 (mouth) & 4,000(mouth) & 6,400 (mouth) \\
\hline $\begin{array}{l}\text { Annual sediment load, } \\
\text { tonnes/year* } 10^{6}\end{array}$ & 18.4 & 190 & 80 & 1,900 & 400 \\
\hline $\begin{array}{l}\text { Specific sediment yield, } \\
\text { tonnes } / \mathrm{km}^{2} / \text { year }\end{array}$ & 74 & 4,362 & 100 & 2,470 & 417 \\
\hline $\begin{array}{l}\text { Sediment yield per water } \\
\text { volume, tonnes } / \mathrm{m}^{3} * 10^{6}\end{array}$ & 170 & 4,300 & 170 & 15,000 & 2,000 \\
\hline
\end{tabular}

The biggest river in Nepal is the Koshi. It is the third largest river with origin in the Himalayan Range. $85 \%$ of the runoff occurs during June to September and $98 \%$ of annual sediment load occurs at this time (Mahmood, 1987). Data from the flow gauge reading as well as sediment sampling at Barahkshtra, Chatara of Koshi River showed the average annual sediment yield is 2,800 tonnes/km2/year (Mahmood, 1987; White, 2001).

\section{HYDROPOWER DEVELOPMENT AND CHALLENGES}

\subsection{Historical background}

The 500 KW Pharping Power Plant which was commissioned in 1911 is the first hydropower installation in Nepal. In 1936, the $640 \mathrm{KW}$ Sundarijal Hydropower Plant was commissioned and in 1965, the $2.4 \mathrm{MW}$ Panauti Hydropower plant was installed.

The 92 MW Kulekhani Hydropower Plant, (I and II) commissioned in 1982, is the only project offering seasonal water storage in Nepal. The 144 MW Kali Gandaki-A Hydropower Project, commissioned in 2003 is the biggest hydropower project in Nepal so far. Most of the Hydropower Plants in Nepal are owned by the governmental agency called Nepal Electricity Authority (NEA), and most of the projects were designed, constructed, and financed by international consultants, contractors with the support

from international assistants. However, recently a few hydropower installations took place from private sector also.

Local capacity is also getting competence on planning, design and construction of hydropower projects. For example, the 20 MW Chilime Project and 3 MW Piluwa Project which were commissioned in 2003, were designed, and constructed by Nepalese experts. The projects fund was obtained from local sources. These projects have improved the confidence of Nepalese engineers and also demonstrated their capability to build plants with domestic technical and financial resources.

Private hydropower developers also started financing in this sector after 1992, when the government adopted new hydropower policy and electricity act. In particular, Butwal Power Company (BPC), Himal Power Limited (HPL), Bhote Koshi Power Company (BKPC), Hydro solutions, Sanima hydropower, National Hydropower Company (NHPC) and other have already started generation. The total generation capacity of the hydropower projects owned by the private sectors is more than $120 \mathrm{MW}$.

\subsection{Opportunities and challenges}

So far only about $1.5 \%$ economically feasible hydropower potential is developed; Nepal 
has a huge opportunity for hydropower development. NEA is carrying out different levels of investigations for identification and recommendation for further study both of storage and RoR projects in Nepal. A number of projects have been identified for development; however, no strong commitments have been made from any developers or investors to develop these projects.

Although, hydropower is considered a major natural advantage for Nepal, its development has been extremely challenging. The challenges are directly related to technical, economical, social as well as political problems in Nepal. Technical problems related to country's geological, topographical, and hydrological features provide large complications for the development of hydropower projects. Government instability is a serious issue in development works in all the sectors.

Nepal's own resources can not meet the financial investment needed for the large scale hydropower development. Today, it is not easy to obtain assistance from the international financial institutions for the hydropower development. A major reason for this is environmental and social impacts linked to the development of hydropower projects. Often environmental issues are misrepresented and this delays, or in some cases stops, the development of hydropower project. The World Bank had withdrawn from the Arun III Project in 1995 in Nepal (WCD, 2000). Together with environmental and social impacts of this project and the government instability might be the reason behind it.

It is also possible to get financial assistance from private developers and investors. However, financial institutions as well as private developers are still not coming forward to fund hydro projects in view of longer pay back period. Long construction phase and high upfront cost does not go well with financial institutions and private developers which in turn look for more spread interest as well stipulations in other terms and conditions.

On the other hand to attract serious and sound private investors, the projects must have reliable hydrological and sedimentological data available. In the international workshop on "Sediment Management of Successful Hydropower Development" which was held in September 2001 in Kathmandu, Professor Haakon Stole (2001) stated that it will be almost impossible to obtain international finance for seasonal water storage schemes, without having reliable and good sediment data. He further added that private developers will not collect sediment data for 10 to 15 years before they actually know whether they have an attractive project or not. It is risky for any investors to finance in the hydropower projects with deficit and unreliable data (Støle, 2001).

Hence, to get financial assistance from international financial institutions or private investors for any future planned projects, reliable hydrological and sedimentological data with precise environmental and social impact mitigation plans should be made available. However, neither long term reliable sedimentological data are presently available, nor the concern authorities and organizations are focusing seriously on these issues mostly, because of financial constraints. Despite adequate availability of surface water and hence, the opportunity of development of hydropower in the country, sedimentation has been providing major challenge for sustainable hydropower development. 


\section{SEDIMENT STUDIES AND RESEARCH}

\subsection{General}

The measurement of suspended sediment load began with the beginning of hydrometry in Nepal; however, the sediment data collection system did not receive the same priority as the other hydrometric measurements (Sharma, 2001). Department of Hydrology and Meteorology (DHM) is a government agency responsible for all the hydrologic and meteorological monitoring activities including sediment in Nepal. It has about 25 sediment sampling stations (only 20 stations are in operation) located mostly in the middle mountain region in the major rivers of Nepal (Bhusal, 2005). The first flow gauging station in Nepal was established on January 1st, 1961 in the Asara Ghat of Karnali River whereas sampling of the suspended sediment was started in the same gauging station in 1964 by DHM (DHM, 2004).

Besides DHM, there are some other organizations involved in different aspects of sedimentation studies in Nepal. NEA, BPC and HPL are also involved in several aspects of sediment studies and research for their own hydropower plants. Hydrolab Pvt. Ltd is one of the leading agencies in private sector dealing with sedimentation studies. It has a capability to provide all kind of modern sediment research and studies.

The Department of Soil Conservation and Watershed Management (DSWM) is responsible for soil conservation by different means including watershed management. Water and Energy Commission Secretariat (WECS) is interested in sediment transport and deposition particularly in areas of potential hydropower projects. Department of Water Induced Disaster Prevention (DWIDP) is focusing on training aspects and it has already started to provide training to the technicians in the field of erosion and sedimentation. Some private consultants are also dealing with sediment studies based on terms of reference (TOR). After the start of master course in Water Resources Engineering in 1998, the Institute of Engineering, Pulchowk Campus is also working in this field.

\subsection{Sediment studies at RoR projects}

RoR hydropower projects play a vital role in the national electricity power system in Nepal. RoR projects contribute more than $80 \%$ of the total hydropower production in Nepal and the biggest hydropower project, Kali Gandaki-A (144 MW) in Nepal is a RoR type. Based on author's report (Sangroula, 2005) very little information on sedimentation was available for any RoR projects prior to their planning in Nepal. The available information on sediments was also not holistic and the projects were designed based on the general knowledge about the sediment pattern in the Himalayan Region. As a result, most of the RoR projects in Nepal faced severe sediment induced problem right after their commission.

A sediment Monitoring Unit (SMU) was established in the MHP project to collect samples and analyze the data right after the project commissioned in 1989, although, sediment data were also collected during project formulation. This is the advanced sediment laboratory in any hydropower project in Nepal, owned by the NEA. The traditional type of data collection and analyses are used in this project. The studies include concentration analyses, sand break analyses particle size distribution (Kayastha, 1999). Sediment samples from other hydropower plants are also being analyzed in this monitoring unit.

A new era of sediment studies and research in Nepal has been initiated after the commission of $12 \mathrm{MW}$ Jhimruk and $69 \mathrm{MW}$ Khimti I Hydropower Projects. These projects are developed and owned by BPC 
and HPL and commissioned in 1994 and 2002 respectively. Together with conventional sediment studies, advanced sediment research has been under taken in these projects.

\subsection{Sediment studies at storage projects}

The 90 MW Kulekhani Hydropower Project which was commissioned in 1982 is located in the Middle Mountain zone of Nepal. So far, this is the only project offering seasonal water storage in Nepal and the project plays a vital role in the national electric power system in the country. This project has lost more than $25 \%$ of its capacity in a little over 20 years. Inasmuch as this is the only project offering seasonal water storage in Nepal, such a loss of capacity is a matter of serious concern to Nepal. An attempt has been made to study the sedimentation in the reservoir and also work out strategies by which the sustainability of the reservoir is ensured.

The sedimentation monitoring activities carried out by the author between 2003 and 2004 included the establishment of flow measuring and water sampling systems in the streams flowing into the reservoir to estimate sediment load entering to the reservoir, taking sediment samples from the reservoir and conduct the bathymetric survey of reservoir. The results and findings of the sedimentation monitoring activities are available in Sangroula, 2006

In June 2003, two flow gauging stations as well as a system for water sampling were established in two major streams flowing into the reservoir. The flow gauging stations are located at Tashar in Palung Khola and at Markhu in Chitlang Khola. The Tashar station is located about $300 \mathrm{~m}$ upstream of the outflow point at HRWL; while the Markhu station is located close to the mouth of the reservoir. The catchment areas covered by the Tashar and Markhu stations are 66 $\mathrm{km} 2$ and $23 \mathrm{~km} 2$ respectively. The total catchment area covered by these two streams is about $70 \%$ of the total catchment. An attempt was made to establish gauging station and a system for water sampling in other streams, but due to the inaccessibility of the stream it was not possible.

The established stations are manual stations that consist of a staff gauge and regular readings are taken by an observer. A singlegauge station was established in both streams. The assumption behind the singlegauge is that the stage in the cross section is a unique function of the discharge only. In the Tashar and Markhu sections single-gauge station will provide sufficient good result, because of no backwater effects and stable hydraulic control.

The gauge reading and water samples were taken twice a day. The data recording started on June 9 and lasted to the end of September for 2003, and for 2004 data recording started on June 21 and lasted until September 18. Altogether 220 stages point were recorded in 2003 and 178 in 2004. This is the monsoon time in Nepal and the major parts of the flow as well as sediment load are expected to be transported by rivers during this time. The velocity measurements were carried out by using a SEBA-Universal current meter. Velocity was measured using the sixthtenths-depth method. Unfortunately flood discharges were not measured because of the safety and logistic problems. Therefore no direct measurements are available for the high flood stages. High discharges are calculated by the slope-area method (Dingman, 2002). Figure 3.1 demonstrates the establishment of gauge reading, water sampling and analysis activities. 


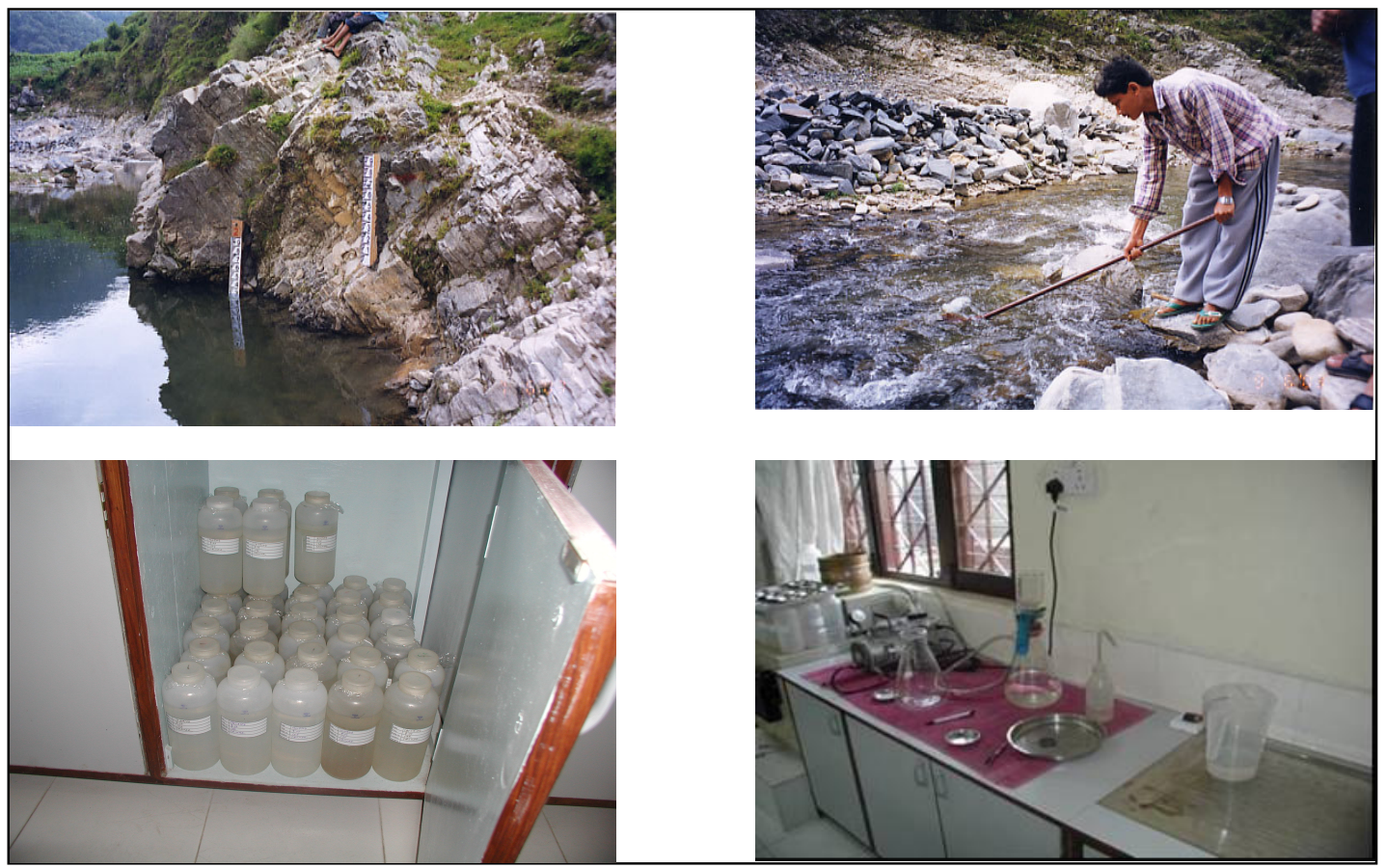

Figure 3.1: Sediment monitoring activities

Reservoir surveys were carried out by the author using improved technology for recording and processing of bathymetric data in November of 2003 and 2004. This is the contour method of surveying and it is applied for the first time in Kulekhani Reservoir. An automated data collection system consists of a field computer with GEODOS software, a Global Positioning System (GPS), and an echo-sounder. In order to minimize errors and to obtain higher accuracies a Differential Global Positioning System (DGPS) technique is adopted for positioning for the Kulekhani Reservoir survey. The GARMIN GPS35 with GPS L1 antenna was mounted on the tripod at a point with known coordinates (Northing, Easting and Elevation). The rover was fixed at $2 \mathrm{~m}$ high wooden pole mounted on the side of the boat (see Figure 3.2). 


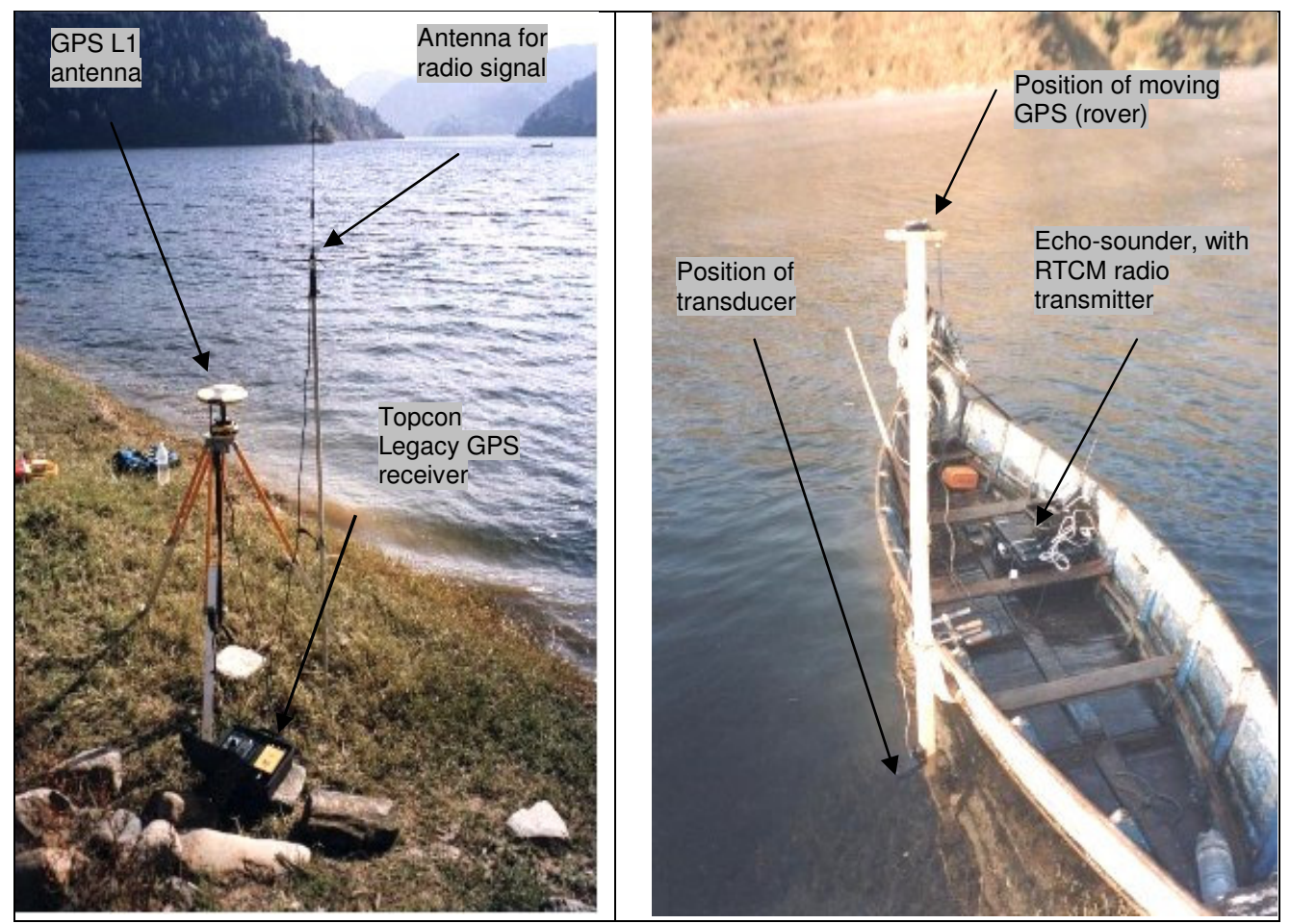

Figure 3.2: Base station and survey boat in the Kulekhani

A minimum numbers of 4 satellites and a maximum numbers of 8 satellites were traced during the survey in 2003 and 2004. More than 6 satellites were traced most of the time. The average value of Position Dilution of Precision (PDOP) is 1.5 and the average number of satellites was more than 6 . USACE (2003) reported that for such survey the PDOP values in the range of 4-5 are considered very satisfactory while PDOP values greater than 10 are considered very poor.

Horizontal positioning data and digital depth data were logged directly onto PSION WB field computer equipped with GEODOS software. Horizontal position was recorded in the Universe Transverse Mercator (UTM) system. The UTM zone number for this area of Nepal is 46. At an average boat speed of $2.5 \mathrm{~km} / \mathrm{h}$, data $(\mathrm{X}, \mathrm{Y}$, and $\mathrm{Z}$ ) were collected at every $5 \mathrm{~m}$ along the survey track lines. About 7000 data points were traced in 2003 and that of 11000 in 2004. For more information readers are requested to refer Sangroula, 2006.

\section{CONCLUSIONS}

Hydropower development is one of the most prominent resources for future economic development of Nepal. Most of the developed projects have not been yielding expected output primarily due to underestimation of sedimentation problems. RoR types of hydropower projects are not able to meet the demand of power for the country especially during dry season of the year. So, there is a need for development of more storage projects in near future. NEA is studying the possibilities of development of storage projects. However, it is necessary to understand that sustainability of storage projects depends on proper handling and the management of sediments.

Data on sediment loads in many Nepalese rivers is inadequate and those available data are also for a short duration. On the other hand, natural disaster is very frequent in the Nepalese Himalaya, which creates tremendous amount of sediment load. Land slide and mass wasting are very common in Nepal during monsoon season. Every year many people are killed due to floods and land 
slides. Nepal lies in the earth quake active zone. Small scale earth quakes are regular in different parts of the country. These natural disasters create high sediment load in the river. Hence, proper documentation and record of such events are important for planning and designing of storage projects in the country.

Sedimentation is a complex issue and to understand this process long-term data are needed. The study made by the author provides a small piece of knowledge. This is the initial stage of the study and the author is planning to develop Kulekhani Reservoir database. Such database will be useful for future sediment researcher and also for the numerical modeling of sedimentation processes in the Kulekhani Reservoir.

\section{REFERENCES}

[1] Bhusal, J. K., 2005. Sediment management in some catchment of Nepal. Proceeding of the India Hydro 2005. International workshop on sediment management in Hydro project, New Delhi, India.

[2] DHM (Department of Hydrology and Meteorology). 2004. Sediment sampling stations, basic stations description in Nepal. Web site: http://www.dhm.gov.np/sedi.shtmi, http://www.dhm.gov.np/basic_stations.s html (downloaded on 2nd June 2004).

[3] Dingman, S.L., 2002. Physical Hydrology, second edition. Prentice Hall, Upper saddle River, New Jersey 07458, USA.

[4] Galay, V. J., Schreier, H., Bestbier, R. 2003. Himalayan sediments issue and guidelines, CD-ROM with entitled "Himalayan sediments: Issue and guidelines". Water and Energy Commission Secretariat, HMG, Nepal.

[5] Kayastha, G. P. 1999. Sediment problems, its impact and management at Marsyangdi Hydropower Station, Nepal. International seminar on Optimum use of Run-of-River hydropower schemes, Trondheim, Norway, June 21-23, 1999.

[6] Mahmood, K., 1987. Reservoir Sedimentation: Impact, Extent and Mitigation. World Bank Technical Paper 71, Washington, DC.

[7] Pandey, B., 2003. "Renewable energy data of Nepal 2003 (with access-toelectricity data" published by Community Awareness Development Centre (CADEC).

[8] Sangroula, D. P., 2006. Sedimentation and Sustainability of the Kulekhani Reservoir. A Himalayan Case. PhD thesis, NTNU, Trondheim, Norway.

[9] Sharma, K. P. 2001. Sediment on the Mountainous Rivers of Nepal, Department of Hydrology and Meteorology, HMG, Nepal.

[10] Støle, H. 2001. Keynote lecture on International workshop on "Sediment Management of successful Hydropower Development" Kathmandu, Nepal

[11] USACE (United States Army Corps of Engineers)., 2003. Engineering and Design, EM 1110-1-1003, NAVSTAR Global Positioning System Surveying, Engineering Manual. Website:

http://www.usace.army.mil/inet/usace-docs/engmanuals/em1110-1-1003/toc.htm

[12] WCD (World Commission on Dams), 2000. Dam and development, a new framework for decision-making, the report of the World Commission on Dams.

[13] White, W. R., 2001. Evacuation of Sediments from Reservoirs. HR Wallingford, London: Thomas Telford.

[14] WWC and IHA (World Water Council and International Hydropower Association), 2003. 3rd World Water Forum. Sustainable use of water for energy, country report from Nepal, Kyoto, Japan. 